\title{
Progressive view on social justice: Netizen opinions about social justice warrior
}

\author{
Hartanto, ${ }^{1,2 *}$ Subandi, ${ }^{1}$ Olga Pavlova ${ }^{3}$ \\ ${ }^{1}$ Faculty of Psychology, Universitas Gadjah Mada, Yogyakarta - Indonesia; ${ }^{2}$ Faculty of Psychology, Universitas \\ Widya Dharma, Klaten - Indonesia; ${ }^{3}$ Department of Cross-Cultural Psychology and Psychological Problems of \\ Multicultural Education, Moscow State University of Psychology and Education, Moscow - Russian Federation
}

\begin{abstract}
Social justice warrior (SJW) is a pejorative term for individuals who fight for equality, environment, and gender. Because their progressive morals radically differ from the predominant values, the so-called social justice warriors spark controversies. This study aimed to describe netizens' opinions about SJW and describe the dynamics of conflict or support in more detail. Text mining and opinion coding were used to elicit research data. The opinions that we gathered were analyzed in 2 stages: sentiment analysis and content analysis. The results of sentiment analysis are negative (445), neutral (86), and positive (90). Content analysis of the negative opinions showed the characteristics of sarcastic, rude, critical, and contemptuous (mocking/disrespecting). The style of positive sentiments (comments congruent with the phenomena) is divided into supportive, empathic, and motivational opinions. Negative opinions are more dominant because of netizens' self-acceptance, the effects of informal social control in cyberspace, SJW's presumed social non-compliance, and doubts of objectivity. Positive opinions can be explained by criticism of social contract theory, namely the demand to be more supportive of minority groups, sensitivity, and empathy (the ability to feel other groups' social conditions and environmental conditions).
\end{abstract}

Keywords: Social Justice Warrior; SJW; sentiment analysis; content analysis

\begin{abstract}
Abstrak: Fenomena social justice warrior (SJW) adalah sebutan bagi individu yang memperjuangkan aspek kesetaraan, lingkungan dan gender. Karena moral progresifnya memiliki perbedaan dengan apa yang selama ini ada, kerapkali menuai pertentangan. Penelitian ini bertujuan mendeskripsikan opini netizen mengenai SJW dan menguraikan lebih detail dinamika konflik atau dukungan. Metode dengan text mining dan koding per opini. Opini yang terjaring dianalisis secara 2 tahap: analisis sentimen dan analisis isi. Hasil analisis sentimen adalah negatif (445), netral (86) dan positif (90). Analisis isi dari opini negatif yaitu karakter opini sarkas, kasar, kritis dan kontem (mengejek/tidak menghargai). Karakter opini positif (komentar yang kongruen dengan fenomena) terbagi menjadi opini supportif, opini empati dan motivatif. Negatif opini lebih dominan karena karakter penerimaan diri, efek dari informal social control dalam di dunia maya, menganggap bentuk dari ketidakpatuhan sosial dan keraguan terhadap objektivitas. Opini yang bersifat positif dapat dijelaskan oleh kritik terhadap social contract theory yaitu tuntutan untuk lebih mendukung pada kelompok minoritas, kepekaan dan emosi empati untuk merasakan tidak hanya kondisi sosial kelompok lain, namun juga kondisi lingkungan.
\end{abstract}

Kata Kunci: Social Justice Warrior; SJW; analisis sentimen; analisis isi

\footnotetext{
*Corresponding Author: Hartanto (hartanto@mail.ugm.ac.id). Faculty of Psychology, Universitas Gadjah Mada, Jl. Sosio Humaniora
} Bulaksumur, Daerah Istimewa Yogyakarta 55281 - Indonesia. 


\section{Introduction}

In line with the American Psychological Association (APA), spirit promotes social justice in psychology (Leong et al., 2017), including racial justice, minority groups, and cultural diversity; substantial research is needed to cover these broad issues (Smith \& Pickren, 2018). In the Theory of Justice, John Rawl (1973) defines justice as a set of ethical standards regarding what is right or wrong and fairness as our ability to make decisions appropriately based on the conditions. Rawl's basic theory of justice intersects with many disciplines, including psychology, social sciences, and economics (Sabbagh \& Schmitt, 2016). From the sociological perspective, justice is a manifestation of communal and societal forces, whereas, in psychology, justice is the combination of individual-level interactions and situations. Within the economic context, justice manifests in the concept of homoeconomicus, where rational and result-oriented behaviors are beneficial (consequentialist). When Rawl proposed the term "reflective equilibrium", he also realized that there existed conditions and principles at the individual level that is "not in reflective equilibrium"; therefore, an essential foundation capable of absorbing all of this disequilibrium must be present and maintained. Still, according to Rawl, because justice is described as a moral standard in the rules of what is good and right (rightness), then it becomes the first virtue of basic social structure (Rawl, 1993). Problems and social inequality arise when there is an imbalance in allocating the resources evenly in this basic structure (Schäfer et al., 2015). The could lead to the emergence of a new movement.

In the middle of 2015, a socio-political phenomenon emerged in the digital world that the Lexico Oxford digital dictionary added it to the list of new words. This phenomenon is referred to as Social Justice Warrior (SJW) and is defined as " $A$ person who expresses or promotes socially progressive views." Until now, it is not clear when this term emerged or who coined and introduced it, but Vox Day (2015a) states that this term first appeared around 1990. In his book, Thomas Sowell also adds that the social justice movement aims to eliminate unnecessary disadvantages. This term is known as Cosmic Justice, which refers to the epiphanic process of social justice (Sowell, 2001). This mindset then spread to every individual thought of people who share the common goal of carrying out the social balance on a large or small scale and dedicating themselves to eradicating the behavior or social structure that is considered problematic and afflicting others. Sowell insists that social action motivation is more accurate and valuable than the consequences in the future. Based on these characteristics, it is obvious that almost all SJW seem to emphasize moral and social values compared to other values in each of their activities.

Although the term SJW has been known for a long time, its popularity is primarily influenced by information development in the digital world (Schejter \& Tirosh, 2015). This phenomenon has lately resurged in Indonesia due to at least two incidents: a large-scale demonstration and riots in Papua. The massive publicity of these events helped popularize the term SJW. People talked about it on social media. Additionally, the issue of fairness and justice has become a trending topic in cyberspace forums or online communities (Strimling \& Frey, 2018), gaming communities (Voorhees et al., 2012), and other social movement communities (Jones et al., 2019). Following Schejter and Tirosh's description above, digital social media development involves the fusion of 
old and new technology to disseminate information using new features, namely digital space, which focuses on individual responses to information. From this, it follows that the online community is given more freedom than they previously had. This new feature gives way to variations in the way individuals assess and make decisions about information.

The issues brought up by SJW vary, but their main concern is usually about social problems plaguing a country, like equality of gender rights (Gundy, 2014), minority issues (Haller et al., 2018; Madon et al., 2017), and human rights (Craig, 2012). The above problems are very closely related to the sentimentalism of moralism that was initiated by David Hume. Eventually this moral sentimentalism developed and served as the basis of the ethical consequentialist movement led by Jeremy Bentham (Driver, 2011) and partly being the basis of deontologist ethics of Immanuel Kant (Sneddon, 2011). Both of these schools, consequentialists, and deontologists, examine morals at the individual level. Deontological ethics presumes that the principal basis in a moral dilemmas is the action, not the final consequences (Greene, 2015; Hales, 2009; Mudrack \& Mason, 2019). As individual behavior is driven by emotional morality (Greene, 2015; Haidt, 2001), one of the strengths of SJW is the sensitivity towards conditions what were previously considered a normal reasonable, while the truth is, those conditions are a far cry from the values of fairness and justice. Therefore, SJW standards are slightly different from popular standards, and they are prone to generating a lot of opinions and attitudes.

Even though the SJW phenomenon has become a trending topic in social media, especially Twitter, preliminary field studies show that not many people are aware of this social movement in the digital world. The preliminary research study concludes that SJW only circulates and echo-chambering (Auxier \& Vitak, 2019; Garimella et al., 2018), among particular segments of social media users, namely social media accounts that concern themselves with socialpolitical issues and highly controversial matters. The researcher sees that differences occur even among social media platforms themselves (Facebook, Instagram, and Twitter) differences occur. In addition to the above reasons, the selection of opinions and responses to an event or social phenomenon will yield more accurate results when researchers used the method of "mining of texts" (Vairetti et al., 2020). The data will be in the form of individual opinions and attitudes towards the SJW phenomenon.

This study mainly aimed to describe netizens' attitudes, sentiments, and social representation in the context of SJW phenomenon in cyberspace. To quote Susilawati and Hidayat (2019), "social representation is a collection of knowledge generated by daily phenomena, which can affect people's way of thinking and bring changes.". Moreover, in concordance with intergroup emotional theory (Goldenberg et al., 2016), an intergroup appraisal that given by each group could spark ANCODI (ANger, COntempt, and DIsgust) hypothesis (Frank et al., 2015) even in an online community (Kim \& Wojcieszak, 2018).

Due to the rapid emergence of this phenomenon, which provoked many controversies, we were curious to find out why these variations of opinion occur and the repercussions of these variations in cyberspace. We felt the need to disclose netizens' responses to this phenomenon to understand the dynamics within netizens' diverse opinions. The results that emerge can 
serve as a reference in the decision-making process on debatable issues, especially social media.

\section{Method}

This research used a qualitative approach. Data from netizens' opinions and tweets are mined (text mining) directly and processed (sorted and cleaned) using the bags of words method. Corpus analyzed using positive words, and negative words using a formula written in $\mathrm{R}$. Sentiment lexicon from Bing Liu (2015) were translated and implemented for analysis. After corpus analyzed, continue for coding-word content analysis using the RQDA package (Huang, 2018). The tweets collected and analyzed for this study are approximately 500-1500 tweets. Tweepy API module offers two choices, standard or premium type; the difference between them is the limit of tweets that can be retrieved and crawled. Because the Twitter accounts that we used in this study share the same token, the standard type rules apply (Dorsey, 2019). Preferred tweets are those written in Indonesian language using ISO-639 code. The search for the right words starts with the keywords "Social Justice Warrior," "SJW," and "Social Justice Fighters." The selection of tweets focused on the main tweet, not retweet (RT). RT counted as additional data.

\section{Results}

Tweet selection resulted in 1149 contents, which were classified into the following: 621 original opinions and 528 retweets about SJW, 90 positive opinions, 86 neutral opinions and 445 negative opinions. Irrelevant tweets were deleted; for example, if SJW directs the API search engine to the regional names, abbreviated nicknames, or other things that were coincidentally mined, it they would be automatically deleted. The text mining of netizens' opinions was done naturallt; we did not explicitly instruct respondents to express their opinions, nor did we raise questions about their but we let the statements surface when the netizens voluntarily express them commenting on some phenomena. However, this method has its advantages and drawbacks. This method enables the researchers to describe the actual conditions, but the data it generates are heterogeneous, and they must be processed using various techniques before the analysis.

We analyzed the data in two stages, namely sentiment analysis and content analysis. Results of the sentiment analysis show that the majority of opinions about SJW are negative. The results appear to show that netizens are not so enthusiastic about the SJW phenomenon in cyberspace. In fact, some opinions associate SJW with other objects and label it with derogatory terms such as paper SJW, plastic SJW, flood SJW, and culinary SJW. The term refers to individuals who criticize others who have the nasty habits of to wasting paper, using plastic irresponsibly, or individual who criticize disaster-prone behavior, and even those who make themselves culinary ctitics. The term SJW is also associated with "buzzers" and "pansos" word in cyberspace.

For negative tweet, the researchers conducted a content analysis to explore the data. From the analysis we obtained four characters of public opinion in a negative tweet about SJW, namely the tone of critical judgment, sarcastic/ satirical, rude, and contemptuous (mocking). Analysis of a positive tweet resulted in three-character opinions about SJW: supportive, empathic, and motivational opinions. In some opinion's netizens try to explain that SJW uses a different moral standard that differs from ordinary people. In the 
environmental aspect, empathic opinions persuade fellow netizens to be more thoughtful and caring towards the environment. Following Rawl's basic structure, both negative opinions and positive opinions are related to the latest social society topics, namely gender and disaster/

\section{Figure 1}

Barplot Negative Opinions

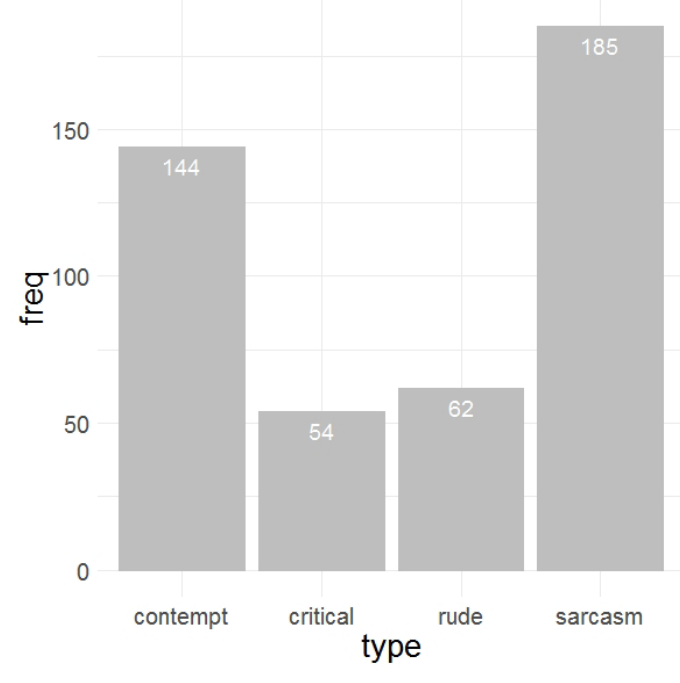

environmental issues. Finally, the neutral tweet consists of only 86 tweets, where the majority of tweets do not indicate the intention and points regarding the direction of opinion. Thus, sentiment and content analysis are focused on the category of neutral opinion.

\section{Figure 2}

Barplot Positive Opinions

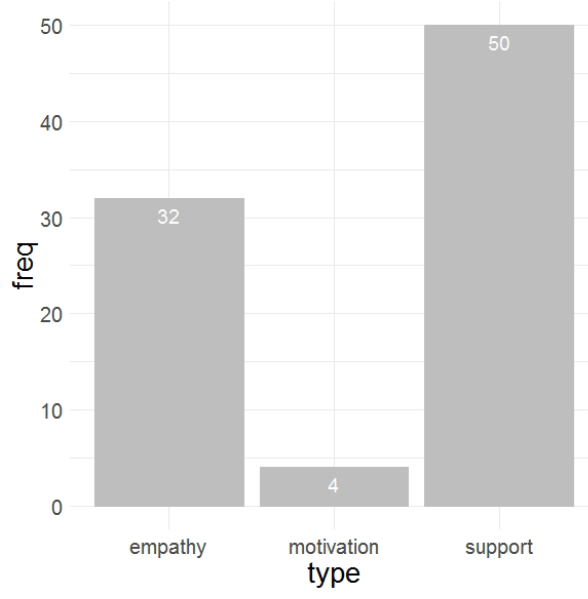


Figure 3

Wordcloud Negative Opinions

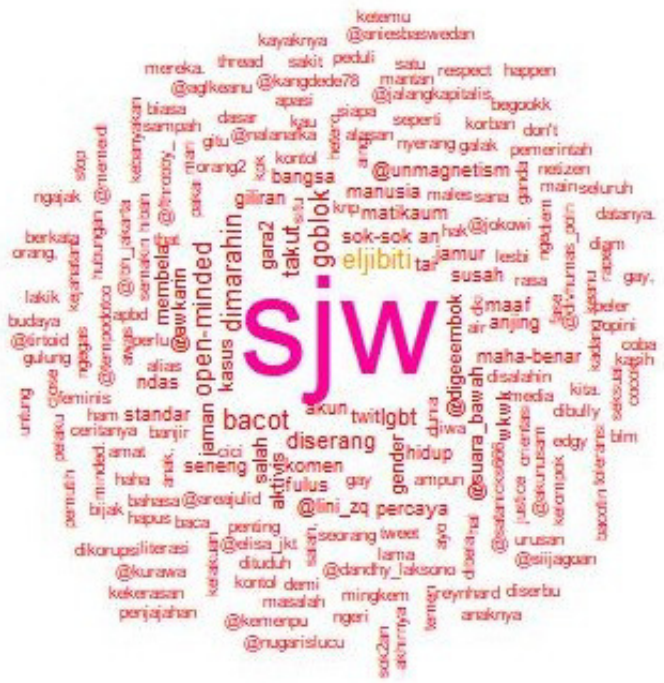

Figure 4.

Wordcloud Positive Opinions

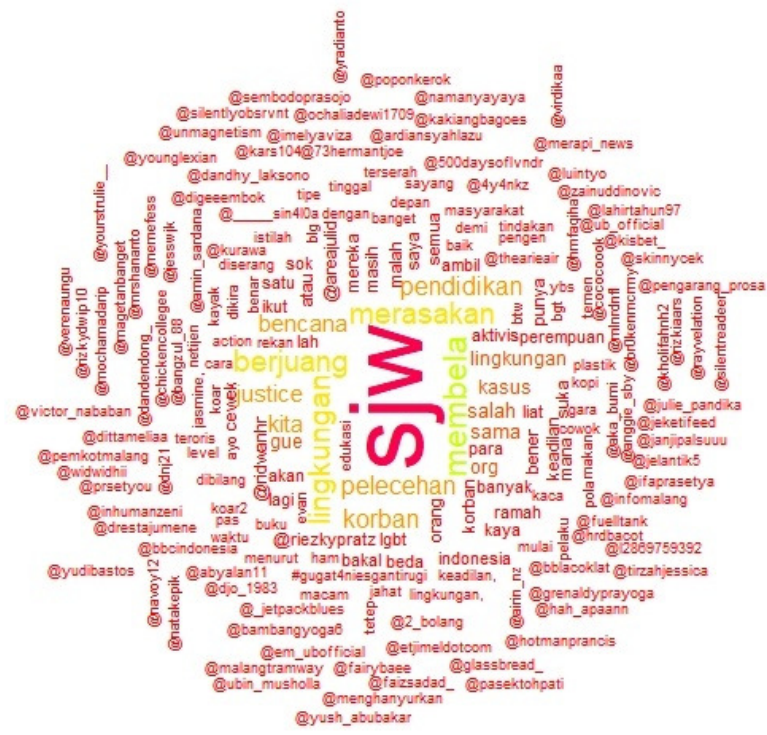


Table 1

Opinions and RTs Description

\begin{tabular}{llll}
\hline Label & Freq & Opinions & Total \\
\hline Rude & 62 & & \\
Sarcasm & 185 & Negative & 445 \\
Contempt & 144 & & \\
Critical & 54 & & \\
Supportive & 50 & & \\
Empathy & 32 & Positive & 90 \\
Motivated & 4 & & \\
RT Positive & 118 & & \\
RT Negative & 392 & Retweet & 528 \\
RT Neutral & 18 & & \\
\hline
\end{tabular}

\section{Discussion}

From the sentiment and content analysis, it was found that opinions were divided into three characteristics, and the majority of netizens' opinions were negative. The character of abusiverude opinion is marked by the use of condescending and insulting words, always using harsh words. Contemptuous opinion is characterized by words intended to mock and insult but not into a rustic tone or sarcasm. It does not express curses or intend to sound like a sarcasm insult; distrust marks the character of sarcasm opinion, and superior comments (deeper than contempt). Still, it looks upside down with the description of opinion. This typical sarcastic comment is rather difficult to polarize with ordinary algorithms. The critical character is more critical of the content and issues being discussed by SJW. The writer demands that SJW brings evidence and references of the concepts and terms in question.

Positive opinions consist of supportive, empathetic, and motivational opinion. The supportive character can be seen from the similarity in moral standards between the individual and SJW in understanding a phenomenon. Supportive comments are characterized by words like openmindedness and a sense of being equals. The empathic opinions show an emotional tone when seeing the phenomenon from the standpoint of SJW. This type of comment is characterized by the words feel and struggle. Motivational opinions are the fewest, characterized by opinions contributing to the change campaigned by SJW.

The meaning of SJW in Indonesian does not shift from the intended meaning in the Englishspeaking countries (Day, 2015b). Although SJW is calling for social justice and principles of equality, ordinary people are less interested because they believe that in their struggle, SJW is 'picky,' -they focus their effort on particular cases. Some netizens even accuse their movement as part of identity politics. Thus, they are doubtful of the value of justice and moral standards that SJW brings. SJW is accused of bringing up trivial matters. For example, they vigorously campaign against the use of improper jokes (dark humor/jokes). In the past, this kind of joke was well accepted and tolerated by some people, but not SJW prohibits humor that certain groups, races, and gender. 
From the psychological perspective, SJW's negative meaning and labels may derive from mistakes in receiving progressive moral messages because of the pre-existing cultural conditions. The concept of self-acceptance is a central issue because, based on sentiment and content analysis, most netizens reject SJW's votes and campaigns. Self-acceptance is characterized by stopping the criticism and developing a new understanding that comes beyond oneself (Bernard, 2014). Some negative variables, such as PTSD (Zhao et al,, 2019) and stress (Rodriguez et al., 2015), were also proven mediated by self-acceptance. Selfacceptance may reduce the negative effect and lead individual to a better mental state. Therefore, self-acceptance is also an indicator of mental health (Xu et al., 2016). Self-acceptance that is felt as a dimension in life and becomes very strong because this attitude is inculcated in eastern cultures for generations. Among Javanese people, this attitude is called called nrimo ing pandum (being submissive to to conditions originating from the Almighty). People who possess nrimo ing pandum mentality, are those who dwell in a culture dominated by a spiritual capital (Charles et al., 2005). It is a principle that teaches individuals how to psychologically cope with years of discontent, and disappointment, at a time where freedom of speech and critical thinking were not yet conceived. More importantly, spiritual capital could reflect the wisdom, values, and transcendental source (Malloch, 2010). Because it has become part of the wider community's life, embedded in mental state unconsciously as the culture teaches it, the concept of nrimo that obstructs the general public accepts the SJW's progressive moral standard. Something does not always have to be constantly criticized. There are moments when you have to stop complaining and accept your being. However, nrimo ing pandum concept is a spiritual character that must be understood within the framework of psychological development. It will be priceless and very valuable when adopted at an appropriate age. When the individual is always thinking critically and not satisfied with what they during the saga of their life, when they should retire and accept everything with grace, it can even lead to failure (i.e post-power syndrome).

Besides, from the social control theory framework, it is known that control can be carried out by legal institutions such as religious authorities, schools, and law enforcement agencies (formal social control) (Deakin et al., 2018). SJW carries out social control through the digital world and takes place informally (the campaign for progressive ideas); as a result, it emerges the opposite attitude and opinion. Initially Brauer and Chekroun (2005), explain that individuals who feel reprimanded by informal social control agents who find faults with their behavior would experience emotions of shame, guilt, and anger. Still, some incidents display emotions of anger and end in murder (Nugier et al., 2007). From our research finding, social control's informal use on social media only provoked 62 rough opinions; sarcastic opinions dominate the rest. When this control is performed by neighbors or people that we know, the emotion of shame and guilt will be present as an attempt to regret and change. Still, when criticism and accusations are leveled against us in cyberspace, where everybody is a stranger to another, sarcastic opinions emerge and dominate. Garmendia (2018) explains that sarcasm is a construct that ranges from humor, criticism to verbal aggression. But they all share one trait: indirectness. 
In contrast with sarcasm, contemptuous opinions are more direct in voicing their views. According to Fischer and Giner-Sorolla (2016) this emotional emotion aims to degrade or insult another object because the sensations felt against that object involve a mixed response between angry emotions and disgust. From here, the majority of these pitched opinions have a degree of angry emotions and disgust emotions from responding to this SJW phenomenon. This opinion ranks second most after sarcasm, and affiliated words are fulus, and buzzer. Contemptuous emotions respond to violations of a community's rules or ideology that first existed (Hutcherson \& Gross, 2011; Russell et al., 2013; Shweder et al., 1997). Pouting about breakthroughs or new ideas that breach the status quo, can be considered as a form of social noncompliance (violated social obligation). This response is compounded by the distrust of netizens towards SJW regarding their objectivity in voicing social justice.

On the other hand, the majority of positive opinions are filled with supportive-themed opinion themes. Some individuals who share a common sense agree with these changes. Even though they are not part of SJW, they are on the same direction. Krasnow (2017) explains that values that sustain morals and identities can undergo evolutionary changes. Moral values' evolution can be explained through criticism of social contract theory (Cosmides \& Tooby, 2008). Today's social contract theory is criticized for at least two different argument flow domains, namely feminists (Held, 1993) and race/ethnicity (Mills, 1987). From the criticism of the two arguments, it can be understood that moral standards have changed, namely, to prevent quid pro quo practice in social justice. Supporting openness to fundamental thinking about fairness for all groups and walks of life is the goal. In a supportive opinion, this fair concept is also illustrated in treating environmental and natural conditions.

The character of empathic opinion falls into the social empathy theory (Segal, 2011). A group of netizens can experience the events that other people feel and expect, which results in insight into changes in the social and economic structure that is still unequal and has a high disparity among several community groups (Adelman et al., 2016). Social empathy is derived from individual empathy, because social media has the advantage of being able to facilitate the personal empathy to merge, social empathy is then built easily easier through some gradual processes, not instantaneously. As Segal explains in more detail, social empathy has four stages: individual empathy, contextual understanding, social responsibility, and finally, social justice. In the contextual understanding phase, people understand the actual problems and obstacles, although they never have real encounters with them. In social neuroscience, along with the mode default network, mirror neuron systems were responsible for brain performance within social engagements, including attempts to understand others' feelings, minds, and behaviors (Lamm \& Majdandžić, 2015). This large network brain performance occurs during the contextual understanding phase. After understanding is generated, the next step is to take into account decisions regarding responsibility and justice. Within the social empathy framework, all individuals must suppress personal gains and losses; thereby, social empathy can be achieved.

Following ANCODI hypotheses above, in ingroup-outgroup favoritism, the SJW pheno- 
menon also defines online group interactions. In which ingroup has confirmation bias following the superiority among groups and is influenced by some negative emotion. As with other group dynamics and organization, the distinctive ideology and its impact are inevitable (Siswanto, 2014).

\section{Conclusion}

This research gives many advantages to study what people were thinking and comment on social media. Various campaigns and social movements eventually start from social media. People polarity opinions are likely the same in general, mainly about agree (positive), not vote (neutral) or disagree (negative), however in level content opinions, the variation occurs. Sarcasm is the opinion that is likely to emerge in negative responses to social movements on social media; however, empathy is the most popular opinion among positive views about social movements. Further analysis of the findings of relationships or correlations between sarcasm and empathy may yield interesting results.

This result also gives a new understanding about the information that spreads in cyberspace, and more importantly, provides us with some critical thinking about this phenomenon. With the ability to think critically, we can spare ourselves from the fallacy of expressing contempt or uttering rude opinions about SJW. Critical thinking could supply us with near-objective information to tell reliable information from those that are not. As APA mentioned earlier, social justice is essential; however, the agents and topics need to be accurate and reliable to bring the voice of equality and justice to life. In the end, however, emotion-driven decision making is easier and more accessible than logic-driven decision making.[]

\section{References}

Adelman, M., Rosenberg, K. E., \& Hobart, M. (2016). Simulations and social empathy. Violence Against Women, 22(12), 1451-1462. https://doi.org/10.1177/1077801215625850

Auxier, B. E., \& Vitak, J. (2019). Factors motivating customization and echo chamber creation within digital news environments. Social Media + Society, 5(2), 205630511984750. https://doi.org/10.1177/2056305119847506

Bernard, M. E. (2014). The strength of self-acceptance: Theory, practice and research. Berlin: Springer.

Brauer, M., \& Chekroun, P. (2005). The relationship between perceived violation of social norms and social control: Situational factors influencing the reaction to deviance. Journal of Applied Social Psychology, 35(7), 1519-1539. https://doi.org/10.1111/j.1559-1816.2005.tb02182.x

Charles, L., Harper, J., \& Templeton, J. (2005). Spiritual information: 100 perspectives on science and religion. Templeton Foundation Press.

Cosmides, L., \& Tooby, J. (2008). Can a general deontic logic capture the facts of human moral reasoning? How the mind interprets social exchange rules and detects cheaters. In Moral psychology, Vol 1: The evolution of morality: Adaptations and innateness (pp. 53-119). Cambridge: Boston Review.

Craig, E. (2012). From security to justice? The development of a more justice-oriented approach to the realisation of European minority rights standards. Netherlands Quarterly of Human Rights, 30(1), 40-64. https://doi.org/10.1177/016934411203000103 
Day, V. (2015a). SJWs Always Double Down: Anticipating the Thought Police. Castalia House.

Day, V. (2015b). SJWs always lie: Taking down the thought police. Castalia House.

Deakin, J., Taylor, E., \& Kupchik, A. (2018). The Palgrave international handbook of school discipline, surveillance, and social control. Springer.

Dorsey, J. (2019). Rate Limit. https://developer.twitter.com/en/docs/twitter-api/v1/rate-limits

Driver, J. (2011). Consequentialism. Routledge.

Fischer, A., \& Giner-Sorolla, R. (2016). Contempt: Derogating others while keeping calm. Emotion Review, 8(4), 346-357. https://doi.org/10.1177/1754073915610439

Frank, M. G., Matsumoto, D., \& Hwang, H. C. (2015). Intergroup emotions and political violence: The ANCODI hypothesis. In J. P. Forgas, K. Fiedler, \& W. D. Crano (Eds.), Sydney symposium of social psychology: Vol. 17. Social psychology and politics (pp. 173-190). UK: Psychology Press.

Garimella, K., Morales, G. D. F., Gionis, A., \& Mathioudakis, M. (2018). Quantifying controversy on social media. ACM Transactions on Social Computing, 1(1), 1-27. https://doi.org/10.1145/3140565

Garmendia, J. (2018). Irony. Cambridge University Press.

Goldenberg, A., Halperin, E., van Zomeren, M., \& Gross, J. J. (2016). The process model of group-based emotion. Personality and Social Psychology Review, 20(2), 118-141. https://doi.org/10.1177/1088868315581263

Greene, J. D. (2015). The rise of moral cognition. Cognition, 135, 39-42. https://doi.org/10.1016/j.cognition.2014.11.018

Gundy, A. (2014). Feminist theory, crime, and social justice. Elsevier Inc.

Haidt, J. (2001). The emotional dog and its rational tail: A social intuitionist approach to moral judgment. Psychological Review, 108(4), 814-834. https://doi.org/10.1037/0033-295X.108.4.814

Hales, S. D. (2009). Moral relativism and evolutionary psychology. Synthese, 166(2), 431-447.

Haller, M. B., Solhjell, R., Saarikkomäki, E., Kolind, T., Hunt, G., \& Wästerfors, D. (2018). Minor harassments: Ethnic minority youth in the Nordic countries and their perceptions of the police. Criminology \& Criminal Justice, 20(1), 3-20. https://doi.org/10.1177/1748895818800744

Held, V. (1993). Feminist morality: Transforming culture, society, and politics. University of Chicago Press.

Huang, R. (2018). RQDA: R-based Qualitative Data Analysis (Version 0.3-1).

Hutcherson, C. A., \& Gross, J. J. (2011). The moral emotions: A social-functionalist account of anger, disgust, and contempt. Journal of Personality and Social Psychology, 100(4), 719-737. https://doi.org/10.1037/a0022408

Jones, C., Trott, V., \& Wright, S. (2019). Sluts and soyboys: MGTOW and the production of misogynistic online harassment. New Media \& Society, 22(10), 1903-1921. https://doi.org/10.1177/1461444819887141

Kim, N., \& Wojcieszak, M. (2018). Intergroup contact through online comments: Effects of direct and extended contact on outgroup attitudes. Computers in Human Behavior, 81, 63-72. https://doi.org/10.1016/j.chb.2017.11.013

Krasnow, M. M. (2017). An evolutionarily informed study of moral psychology. In Moral Psychology (pp. 29-41). Springer. 
Lamm, C., \& Majdandžić, J. (2015). The role of shared neural activations, mirror neurons, and morality in empathy - A critical comment. Neuroscience Research, 90, 15-24. https://doi.org/10.1016/j.neures.2014.10.008

Leong, F. T. L., Pickren, W. E., \& Vasquez, M. J. T. (2017). APA efforts in promoting human rights and social justice. American Psychologist, 72(8), 778-790. https://doi.org/10.1037/amp0000220

Liu, B. (2015). Sentiment analysis. Cambridge: Cambridge University Press.

Madon, N. S., Murphy, K., \& Sargeant, E. (2017). Promoting police legitimacy among disengaged minority groups: Does procedural justice matter more? Criminology \& Criminal Justice, 17(5), 624-642. https://doi.org/10.1177/1748895817692849

Malloch, T. R. (2010). Spiritual capital and practical wisdom. Journal of Management Development, 29(7/8), 755-759. https://doi.org/10.1108/02621711011059194

Mills, C. (1987). The racial contract. Cornell University Press.

Mudrack, P. E., \& Mason, E. S. (2019). Moral reasoning and its connections with machiavellianism and authoritarianism: The critical roles of index choice and utilization. Business \& Society, 58(4), 779-812. https://doi.org/10.1177/0007650316681556

Nugier, A., Niedenthal, P. M., Brauer, M., \& Chekroun, P. (2007). Moral and angry emotions provoked by informal social control. Cognition \& Emotion, 21(8), 1699-1720. https://doi.org/10.1080/02699930601124738

Rawls, J. (1973). Theory of Justice. Oxford University.

Rodriguez, M. A., Xu, W., Wang, X., \& Liu, X. (2015). Self-acceptance mediates the relationship between mindfulness and perceived stress. Psychological Reports, 116(2), 513-522. https://doi.org/10.2466/07.PR0.116k19w4

Russell, P. S., Piazza, J., \& Giner-Sorolla, R. (2013). CAD revisited: Effects of the word moral on the moral relevance of disgust (and other emotions). Social Psychological and Personality Science, 4(1), 62-68. https://doi.org/10.1177/1948550612442913

Sabbagh, C., \& Schmitt, M. (2016). Past, present, and future of social justice theory and research. In Handbook of social justice theory and research (pp. 1-11). Springer.

Schäfer, M., Haun, D. B. M., \& Tomasello, M. (2015). Fair is not fair everywhere. Psychological Science, 26(8), 1252-1260. https://doi.org/10.1177/0956797615586188

Schejter, A. M., \& Tirosh, N. (2015). "Seek the meek, seek the just": Social media and social justice. Telecommunications Policy, 39(9), 796-803. https://doi.org/10.1016/j.telpol.2015.08.002

Segal, E. A. (2011). Social empathy: A model built on empathy, contextual understanding, and social responsibility that promotes social justice. Journal of Social Service Research, 37(3), 266-277. https://doi.org/10.1080/01488376.2011.564040

Shweder, R. A., Much, N. C., Mahapatra, M., \& Park, L. (1997). The "big three" of morality (autonomy, community, divinity) and the "big three" explanations of suffering. - PsycNET. In A. M. Brandt \& P. Rozin (Eds.), Morality and health (pp. 119-169). UK: Taylor \& Francis, Routledge.

Siswanto, Y. (2014). In-group favoritsm pada mahasiswa aktivis ditinjau dari konstrual diri independeninterdependen. Jurnal Ilmiah Psikologi Terapan, 2(1), 184-198. https://doi.org/10.22219/jipt.v2i1.1779 
Smith, M. B., \& Pickren, W. E. (2018). The American Psychological Association in relation to social responsibility and social justice. In 125 years of the American Psychological Association. (pp. 359-391). American Psychological Association. https://doi.org/10.1037/0000050-012

Sneddon, A. (2011). Like-minded: Externalism and moral psychology. MIT Press.

Sowell, T. (2001). The quest for cosmic justice. Simon and Schuster.

Strimling, P., \& Frey, S. (2018). Emergent cultural differences in online communities' norms of fairness. Games and Culture, 15(4), 394-410. https://doi.org/10.1177/1555412018800650

Susilawati, I. R., \& Hidayat, R. (2019). Dilema sosial: Representasi sosial tentang pajak pada Aparatur Sipil Negara. Jurnal Psikologi Sosial, 17(2), 65-74. https://doi.org/10.7454/jps.2019.10

Vairetti, C., Martínez-Cámara, E., Maldonado, S., Luzón, V., \& Herrera, F. (2020). Enhancing the classification of social media opinions by optimizing the structural information. Future Generation Computer Systems, 102, 838-846. https://doi.org/10.1016/j.future.2019.09.023

Voorhees, G. A., Call, J., \& Whitlock, K. (2012). Dungeons, dragons, and digital denizens: The digital roleplaying game. Bloomsbury Publishing.

Xu, W., Oei, T. P., Liu, X., Wang, X., \& Ding, C. (2016). The moderating and mediating roles of selfacceptance and tolerance to others in the relationship between mindfulness and subjective well-being. Journal of Health Psychology, 21(7), 1446-1456. https://doi.org/10.1177/1359105314555170

Zhao, Y., An, Y., Sun, X., \& Liu, J. (2019). Self-acceptance, post-traumatic stress disorder, post-traumatic growth, and the role of social support in Chinese rescue workers. Journal of Loss and Trauma, 25(3), 264-277. https://doi.org/10.1080/15325024.2019.1672935 
This page has been intentionally left blank. 